\title{
Local content development projects in Africa
}

\author{
Stephen Mutula' \\ Department of Library and Information Science, University of Zululand \\ Private Bag XI00I, Kwadlangezwa 3886, South Africa \\ mutulasm@mopipi.ub.bw
}

Received: $20^{\text {th }}$ September 2008

Accepted: $29^{\text {th }}$ October 2008

\begin{abstract}
The paper unpacks the concept of 'content' and its derivative 'local content'. It further elucidates on the confusing nexus between 'local content' and indigenous knowledge and asserts that IK is in fact a special form of local content. The benefits of local content to the economy are discussed as are the challenges. The paper submits that contrary to widely held perception, Africa has made good progress towards developing and managing its local content. Several local content initiatives by international agencies as well as regional and national efforts are testimony to this claim. The paper suggests the way forward to enhance local content development in Africa. .
\end{abstract}

Keywords: Local content, Africa, indigenous knowledge, knowledge management, digital content

\section{Introduction}

There are divergent opinions in literature on the meaning of the concept 'content' going by several definitions that are adduced. The lack of unanimity on what constitutes 'content' suggests that even the definition of 'local content' is not cast in stone. This paper starts by unpacking the concept 'content' and later 'local content'. Some literature tends to suggest that if an idea, information, knowledge, etc., is not in digital format then it is not content. For example, Siemens (2003) perceives content as e-journals, images, graphics, video, movies, websites, online databases, e-mails, online news, software, animations, etc. Claiborne (2005) defines content as the stuff on your site. Yet some definitions do not differentiate between the media and content while others perceive content as recorded information or knowledge. Some of the definitions gleaned from the Web follow: content is everything included in a collection (WordReference 2008); content refers to material which is of interest to users, such as textual information, images, music and movies (The Linux Information Project 2005); content means information and experiences that may provide value for an end-user/audience (Wikipedia); content is published information and experiences such as novels, movies, music, game, webpages, presentations, organised data, etc. (Wiktionary). These varied definitions, as diverse as they are, provide a framework for redefining the term 'content' in an attempt to harmonise these variations.

From the definitions above, one can notice a shifting position from the previously held notion that format has to be digital for the object to be 'content'. This notion may perhaps have arisen out of the fact that ICT and the Internet have had a tremendous impact on content creation and distribution processes since 1990s when the Internet revolution gained pace. Besides, during the last few years there has been a growing recognition of the need to generate content and make it available through new media in order to empower communities and lead them to an inclusive knowledge society (UNESCO 2005). Secondly, among these definitions there is less emphasis on the media or conduit (container) but on the 'containee'. Thirdly, the process of generating content (product, process or service) inevitably involves human or intellectual effort. Fourthly, what is 'content' must be of use to the end-user. Based on these divergent definitions, the following definition of 'content' is proffered in this paper: content is an intellectual process that results in a product (e.g. information, knowledge, website, song, dance, record, design, artefact, system, etc); process (e.g. engineering procedure, an algorithm, workflow, rules, etc); and a service (e.g. public service broadcasting, news, advertisement, presentations, content scrapping, video on demand, animations, etc.). It is important in redefining 'content' to however exercise caution so that media or conduit are not confused with content. For example, a computer is not content, but data stored in it; a mobile phone is not content but short message service; a book is not content but the information contained in it; and a website is not content but the information contained in it. Similar interpretation can apply to blogs, social networking sites, digital libraries, digital repositories, TV, radio, newspapers, etc which are often seen as content when in fact they are media or conduits.

I. Stephen Mutula, PhD, is an Associate Professor in the Department of Library and Information Studies at the University of Botswana. $\mathrm{He}$ is currently(2008), a Visiting Professor in the Department of Library and Information Science, University of Zululand, South Africa. 


\section{Local content}

The term local content can be considered a prefix of content or its derivative. Consequently, like content, local content is a creation of the mind or simply an intellectual product. UNESCO (2005) defines local content as the expression and communication of a community's locally owned and adapted knowledge and experience that is relevant to the community's situation. A community in this definition is signified by location, culture, language, or area of interest. Such a community can comprise a whole region, a sub-region, a nation, a village or clan or a group of people with strong cultural, linguistic, religious or common interest links. Ballantyne (2002) perceives local content as the proportion of goods and services produced locally, i.e. development of local skills, technology transfer, use of local manpower and local manufacturing.

The two definitions proffered above have implications in terms of the scope of what constitutes 'local content'. Ballantyne's definition is broad-based and goes beyond informational products (e.g. information, knowledge, data, etc) which often tend to be equated to content. This definition is however consistent with what Ugwanyi (2003) seems to portray when he observes that in Nigeria local content of goods and services in the oil and gas sector is less than five percent, and about 95 percent of the yearly expenditure of about US $\$ 8$ billion (N880 billion) flows out of the country through technical services and goods procured from outside the country. Similarly, ComDev (2008) echoing Ballantyne's definition notes that local content" typically refers to company expenditure on the procurement of local goods and services, community development and direct hiring, employment and building local skills. In contrast, the UNESCO definition intimates a close link indigenous knowledge $(\mathrm{IK})$ and local content. $\mathrm{IK}$ is an intricate knowledge acquired over generations by communities as they interact with the environment (Seepe 200I). In the context of South Africa, IK is perceived as a complex set of knowledge and technologies existing and developed around specific conditions of populations and communities indigenous to a particular geographic area (NRF 2002). In this paper, IK is taken as a special form of local content. The way to distinguish the two is simply to characterise IK and map each characteristic to the local content definition. For example, IK is based on experience, it is often tested over centuries of use; it is adapted to local culture and environment, it is dynamic and changing, it is oral-based, it is acquired and passed to generations, it is in the public domain, it is shared among community members, and it is based on experimentation. The first definition of local content above (Ballantyne 2002) does not seem to reflect much relationship with the concept of IK. However, the second definition (NRF 2002) would seem to accommodate some aspects of IK such as 'knowledge', 'technologies', particular geographic area (or community).

Based on the definitions described above, the following are examples of local content: local web content, IK, locally generated skills, locally generated services, local telephone directory entries, content of theses and dissertations, egovernment content, grey literature content, national or community media content, locally generated songs and dance, organisation records, workflows, national constitutions, personnel management systems, work procedures, community information, mortgage information, an amenities list, housing details, etc.

\section{Benefits of local content}

Before colonisation, Africa relied on endogenous development characterised by reliance by people on their own resources, values, knowledge and organisations that were locally designed for their survival. These local resources were developed and shared to strengthen the resource base of local population, enhance their ability to integrate selected external elements into local practices and broaden the options available to the people, without diluting the local views and practices (Menchu 2007).

Development of local content is gaining a lot of attention internationally (UNESCO 2005). This is because of the understanding that local content provides opportunities for members of the community to interact and communicate with each other, expressing their own ideas, knowledge and culture in their own language. Moreover, locally generated content is more relevant to the consumer, easily accessible, cheaper, promotes community identity and culture, enhances social inclusion, facilitates universal access, etc. ComDev (2008) points out that local content programs, enhance economic development through local procurement of goods and services, employment, and related initiatives. Local content is a significant factor in determining overall competitive advantage; expanding global communication networks enhancing transparency, and the broader stakeholder awareness of social issues.

Through local content, local communities receive immediate benefits such as employment skills development, longer term benefits such as skills transfer through training and direct experience. In addition, successful local content programs create a multiplier effect that can help to broaden and diversify the local economy. For example, the most important company benefit from a successful local content program is the social license to operate, which helps to ensure uninterrupted operations, and enhance company reputation. Other benefits of a local content program may include 
long term cost savings from hiring locally versus paying for staff relocation as well as reduced transportation and logistical expenses associated with local content arrangements (ComDev 2008).

Local content draws on resources in the immediate neighborhood and makes people less dependent on outside supplies, which may be costly, scarce and irregularly available. Moreover, local content provides the means of satisfying internal needs, enhances self reliance, helps bridge intra and extra divides, enhances community access to content and in general gives a community identity as it mirrors real life situation and operations. IK (both tacit and explicit) as a specialised form of local content has been applied in fast-tracking medical experimentation through identification of useful medicinal herbs and plants, and also in conflict resolution and environmental conservation using knowledge of indigenous communities.

Ofcom (2006), the UK Office of Communications (the local telecom regulator), notes that local issues continue to matter to people and digital local content could, in this respect, deliver a range of benefits, including: more relevant local news; improved access to local services; stronger involvement in community affairs; enhanced democratic participation; greater capacity for individuals and local organisations to make and distribute their own content; support for local production and training; and advertisers' access to local markets.

\section{Global local content development in Africa}

Africa now than before is witnessing increased national, regional and international efforts in local content development and documentation since the last two decades following a clarion call by United Nations Economic Commission for Africa (UNECA) to Africans to be involved in the production process (Chivhanga 2000). Several initiatives by development agencies, national governments and institutions are consequently heeding this call. The Technical Centre for Agricultural and Rural Cooperation (CTA) has since 1986 supplied major agricultural databases on CDROM to developing countries including those in African institutions by creating awareness about the potential of information and information technology and providing access to the world's agricultural research. This programme has been successful in creating and publishing local databases on CDROM (Dusink 1991). Another programme, the ExtraMed is a CD-ROM service provides abstracts and full texts of more than 300 health and medical journals published in developing countries. It covers more than 50 titles in Africa. Besides, the Index to South African Periodicals (ISAP) provides abstracts and bibliographic information to more than 680 periodicals and journals published in South Africa.

The G8 Digital Opportunities Task Force in its 2001 Genoa Plan of Action defined an approach to increase access and use of ICT in countries and, in particular, proposed the development of local content through making software applications available, encouraging participation of local stakeholders and expanding the language available on the Internet (DOT Force 200I). During the same Summit, Canada undertook to make a contribution to the DOT Force agenda for Africa by declaring its intent to promote community access through network connectivity and support for creation of local content (Bourassa 2003). Consequently, the Canadian based International Development Research Centre; IDRC initiated telecentres in some African countries such as Zimbabwe, Uganda, and Swaziland (Graham 1997).

The World Bank on its part has mainstreamed IK into development processes in sub-Saharan Africa in order to optimise the benefits of developments assistance to the poor. The Bank uses the web to disseminate IK and has a referral database. In Burkina Faso and Uganda, the World Bank has improved the connectivity and networking capacity of local communications. As a result, rural community telecentres are now used to obtain information from local communities and disseminate knowledge generated to other regions. The World Bank has also a knowledge management system and it is involved in funding efforts to collect document and disseminate indigenous knowledge (Naur 200I). The UK Department for International Development (DFID) in 2002 started a project to assist in the development and exchange of local content in Africa aimed at supporting efforts by poor people in developing countries to create and exchange useful (as perceived by these people) content via ICTs (International Institute of Communication and Development 2002). The project covered Kenya, Uganda, Tanzania, Mali and Zambia. A key element was to document local content lessons for others to learn from. The Open Knowledge Network (OKN) arm of the project provides a 'channel' to disseminate and exchange the content generated in various media and in local languages. The initiative has already generated local knowledge products like CD-ROMs, video-tapes, leaflets, etc (International Institute of Communication and Development 2002).

Bioline International, an online publishing initiative enables some African journals to be available electronically on the Web. It is a collaborative initiative of the University of Toronto Libraries, Canada, the Reference Centre on Environmental Information (Brazil) and Bioline (UK) (Kirsop 2002). Through this initiative, abstracts and full-texts of several African journals can be accessed electronically on the Internet. Similarly, the African e-journals Project (AJEP), an initiative of the Michigan State University, in collaboration with the Association of African Universities (AAU), African Studies Association (ASA), and CODESRIA assists some journals in Africa to be available on- line. Furthermore, Stacos North America Inc. 
has developed a database of the African Universities Dissertations Abstracts (AFUDA) to cover current dissertations that have been accepted for the award of higher degrees in African Universities (Ubogu 2000). Besides, the Africa Journals Online (AJOL), an initiative of the International Network for the Availability of Scientific Publications (INASP) based in the United Kingdom, offers access, via the Internet, to tables of contents and abstracts of African-published journals in agriculture, social sciences, humanities, health and science and technology (Aina and Mutula 2005).

The World Summit on Information Society (WSIS) in 2003 and 2005 respectively provided a framework for an international debate aimed at creating an all inclusive information society (Souter 2007) with emphasis placed on ensuring pervasiveness of ICTs that would in part facilitate creation of local content. The WSIS Declaration of Principles and the Plan of Action noted that public institutions such as libraries and archives, museums, cultural collections and other community-based access points should be strengthened so as to promote the preservation of documentary records, free and equitable access to information (World Summit of Information Society 2005). Similarly, the International Federation of Library Association (IFLA) in its submission to WSIS recognised the extent to which indigenous knowledge needed to be harnessed in the information society and underscored the importance of connecting villages and establishing community access points; connecting universities, colleges, secondary schools and primary schools; creating scientific and research centers; and providing public libraries, cultural centers, museums, post offices and archives with ICT. IFLA stressed the need for special attention to be paid to rural and underserved areas (International Federation of Library Associations 2003).

UNESCO (2005a) has been involved through its Local Content in the Media Programme in boosting the production and dissemination of local content in both the traditional and new media in the most disadvantaged communities of the developing world by training content creators, supporting local content production and enhancing content distribution channels. In particular, UNESCO has helped in training creators of local content, producing local content, distributing local content, developing an audiovisual e-platform, and creating a content photobank. The UNESCO support is directed towards regional, interregional or international training initiatives, where the transfer of know-how between sub-regions or within a region is needed. Training areas focus on the content production chain, such as pre-production work, scriptwriting for television and radio, digital camera and sound techniques, digital editing, post-production, and selftraining through screenings of best examples. The training modalities include development of guidelines, training modules and reference materials, publication of training materials, production of video tutorials, organisation of short-term training courses, hands-on workshops, provision of experts for production screenings and research on latest trends and flows in audiovisual production.

\section{Regional local content development in Africa}

Apart from the internationally initiated local content projects identified above, there are regional positive trends especially towards indigenous knowledge. The Organisation of African Unity in 1980, through the Lagos Plan of Action, placed great emphasis on locally generated information to solve Africa's development problems. The Plan recognised that the strength of the indigenous information systems rested with content of valuable social, scientific and technological information as well as traditional channels of information exchange. The Plan recommended that African countries should enact policies that reflect adequately socio-cultural values in order to reinforce cultural identity. Moreover, the Plan stressed the importance of basic industries and the need to move towards technological capability and self-reliance in the region (Onyango, 1996). Though the Plan did not have any significant impact, it provided a framework for local content development within Africa.

The African Union (AU) declared 200I-2010 a decade for African traditional medicine. The AU in this regard recognised the importance of indigenous knowledge in the continent's health sector. With this declaration, there followed the formation of a number of traditional healer's associations across Africa in Uganda, Tanzania, Zambia, etc (The Standard Ltd 2004) and legislation related to IK. For instance, the South African government put in place the Indigenous Knowledge Systems (IKS) Policy in 2008. This policy is aimed at stimulating and strengthening the contribution of indigenous knowledge to social and economic development in the country (Department of Agriculture-South Africa 2008). Similarly, the revised South African National Forest Act No 84 of 1998 recognises the links between community conservation and commercial forestry. It recognises the role played in people's livelihood by trees, woodlands and the resources. The Act places greater emphasis on the value of indigenous forests and prohibits destruction of indigenous trees without license (National Forests Advisory Council 200I).

African countries through the e-Africa Commission, the ICT arm of New Partnership for Africa's Development (NEPAD) is making attempts at developing local content programmes. The e-Africa Commission aims in part to develop local content that would empower and propel Africans to make a unique contribution to the information society (Harbi 2003; Ford 200I; Mikenga 2005). Elsewhere, the Digital Imaging project in South Africa (DISA) is a non - profit making 
initiative for co-operation among research libraries and archives in Southern Africa on digital imaging. This project is sponsored by the Andrew W. Mellon Foundation. The Project was mooted in order to make accessible to scholars and researchers world-wide, South African material of high socio-political interest that would otherwise be difficult to locate and use, and provide South African archivists and librarians with knowledge of, and expertise in, digital imaging. The key objectives of DISA are to build the capabilities of human resources, and to provide access to scholarly research materials on a sustainable basis (Peters and Pickover 200I).

The National Enquiry Service Centre (NISC) based in South Africa is a database publishing company that offers a platform for publication of both large and small databases with the purpose of providing information for Africa, about Africa and for Africans. NISC publishes databases both on CDROM and the Internet. The databases can be accessed through the NISC bioline service. NISC also maintains a collection of details on potential and existing African databases. It offers access to most titles with the option of CDROM or Internet to cope with telecommunication infrastructure disparities in Africa (Crampton 1998). Similarly, media houses and internet service providers are also at the centre of content development in Africa. For example, Africa Online is a well known African ISP as well as a bandwidth and content provider. It has played an important role in organising Africa's local content on the Web. Africa Online offers single portal of access to information on various countries in Africa on diversity of subjects. It maintains a directory that offers access to different local content (Africa Online Holdings Ltd 2002). Another well known media digital content provider is MultiChoice. It launched a digital broadcaster service in Kenya in 2007 that would stream television content to subscribers' handsets and also enable phone subscribers' access television content. Nigeria, Namibia and South Africa have started the trials for this same service (Southwood 2007).

Another project, the Technology Enhanced Learning Initiative of Southern Africa (TELISA) is an initiative of the Centre for Lifelong Learning in cooperation with several partners such as the World Bank and UN Economic Commission for Africa. It was established to facilitate the establishment of ICTs centres throughout South African Development Community (SADC) region. Through TELISA, a series of information servers to provide appropriate support material to existing institutions, lecturers, teachers and businesses have been set up. TELISA's areas of action include: internet connectivity, information clearing house, institutional connectivity, educator training, and projects (Mutula 2002). Elsewhere, the African Association of Universities maintains a database of African theses and dissertation (DATAD) on CD-ROM that is widely accessible to affiliate member institutions. The aim is to promote information exchange and sharing of research outcomes among member institutions within the continent. On the networking scene, the South Africa's bibliographic Network (SABINET) and Ain Shams University Network (ASUNET) in Egypt are two major bibliographic utilities that are involved in electronic publishing on the African continent. SABINET publishes online the Union Catalogue of Theses and Dissertations at masters and doctoral levels. Similarly ASUNET publishes all its theses online.

The African Online Digital Library - AODL is a project funded by International Development Research Centre of Canada and the National Science Foundation (NSF) of South Africa. It begun in 2000/200I, as the pioneer in African digital library development. It produces multilingual, multimedia materials for both scholarly research and public viewing audiences. AODL serves scholars and students conducting research and teaching about West and South Africa as well as teachers and students of African languages in both the United States and Africa (Ojedokun 2000). Besides AODL, the African Digital Library (ADL) was established by Technikon South Africa's Centre for Lifelong Learning, in collaboration with the Association of African Universities. It is a free public library which was established for users in Africa who have access to the Internet. Likewise, African Virtual University (AVU) Library belongs to the African Virtual University (AVU) in Nairobi, Kenya, an innovative educational organisation established to serve the countries of Africa. The objective of the AVU is to build capacity and support economic development by leveraging the power of modern telecommunications technology to provide world-class quality education and training programs to students and professionals in Africa (Ojedokun 2000).

UNESCO implemented a content development programme known as Initiative for Africa Cartoon Production. This programme was developed based on the rationale that despite efforts by regional broadcasters and the audiovisual community in Africa, children's programmes and in particular computer-animated cartoons, are mostly imported from abroad due to the absence of cost effective production, the lack of ICT equipment and facilities and the lack of people with skills in computer animation. The initiative assembles resources and expertise for the production of children's animated cartoons in Africa. The programme targets regional animators, visual artists, scriptwriters, broadcasters and other media professionals with the aim to build a critical skills base for the production of high quality animated cartoons. It is hoped that this programme will encourage the production of programmes that allow children and young people to hear, see and express themselves using African cultures, languages and life experiences such as African imagery, dialogue and music that draw on the continent's vast oral and pictorial heritage (Aznar 2006).

SA JnI Libs \& Info Sci 2008, 74(2) 


\section{National projects for local content development in Africa}

National projects aimed at local content development are gaining pace in Africa. The cell phone service providers are beginning to exploit the potential of cellular handset for local content publishing. Mobile phone content is becoming more pervasive just like radio broadcasts to many African people in the rural areas. Southwood (2007) observes that for most rural and remote parts of Africa, cellular networks provide the only way for people to make calls or send data because of the dearth of fixed-line phones. Almost 70 percent of the population in sub-Saharan Africa was in 2007 estimated to be covered by a cellular network. The local content accessible through mobile phones includes news broadcasts, music, video, short message service, voice, videoconferencing, etc. Other content includes, Internet services, such as instant messaging and VOIP applications. Though cell phone providers started by providing services within a given jurisdiction, their foot prints are expanding regionally and internationally. For example Vodacom and MTN of South Africa on one hand, and Safaricom and Zain of Kenya on the other, are operating beyond countries in which they were initially incorporated.

E-government projects are emerging also emerging to play a central role in promoting creation and dissemination of local content. Several countries in Africa like their counterparts in the rest of the world aim to provide diverse and effective service delivery (Mutula 2006). E-government is perceived as a panacea to the deficiencies of the traditional form of government where, citizens physically go to government offices to seek services, such as applying for a passport, birth certificate, death certificate or filing tax returns (with the consequent delays arising out of long queues, lost files or the absence of relevant officials). E-government is largely a local content intensive environment that consists of decision support systems such as community information, business information, records-management systems, integrated financial management systems, human resource management systems, communication systems, databases and portals (International Records Management Trust 2004). E-government provides information services of immediate local use to its citizens and is therefore a rich source of local content.

Likewise, several universities in Africa like their counterparts in the rest of the world are increasingly using their webbased online public access catalogues (OPACs) as gateways not only to information outside their libraries but also to their own locally digitised content. For example, at the University of Botswana library the OPAC is used to provide access to among other resources, digitised full-text past examination papers. Likewise, at the University of Pretoria in South Africa, the library provides access to its institutional repository containing partly locally generated content (Pienaar and Daventer 2007). Similarly, Rhodes University also in South Africa publishes electronic theses and dissertations (ETD) and makes them available on the university intranet. Overall, digital education content is increasingly being generated in Africa as, many tertiary institutions especially, universities turn to e-learning. Such digital content consists of variety of learning materials that may vary from basic text to multimedia such as: assignments; reading lists, course notes, course syllabi, course objectives and external content links. In Southern Africa, institutions that have made great strides in implementing elearning, include among others; University of South Africa, University of Johannesburg; Cape Peninsula University of Technology; University of Pretoria, University of Witwatersrand and University of Johannesburg and University of Botswana (Mutula 2006).

Besides, the University of Botswana and Botswana Technology Centre (a state corporation) in collaboration with Meraka Institute (in South Africa) are experimenting with the use of Open Source Software in promoting OpenPhone project. The aim is to develop a community oriented service in the HIV/Aids field. The telephone information service would provide caregivers of children with HIV/AIDS with basic health information they need in home-based care situations. This information service will be provided in Setswana (local language) and English (Chikane 2007).

Beyond academia, Africa has about $80 \%$ of the population using radios to generate and disseminate local content such as news (Jensen 1999; Southwood 2002:5). Moreover, Internet radio connectivity is increasing to provide more opportunity enhanced community access to information (Southwood 2002), though most of them remain commercially driven. They can however with policy change be able to provide local content that would complement e-governance services. Besides, NGOs are playing a significant role in enhancing community use of technology. In South Africa for example, Translate.org.za, an NGO using open source software, translated the desktop, the Web browser, Word processor, Spreadsheet and Mail applications into local languages such as Xhosa, Zulu, Venda and Sotho among others (Translate.org.za 2003; Martindale 2002).

The Mobile Content to Change Lives project funded by the Vodafone Group Foundation is being piloted in Kenya since 2003. The project based in Nairobi, is target youths in slum areas to develop and test mobile content services, before introducing them to other target groups. The first pilot version of the Community News service including, health tips, community events and job opportunities went live in June 2004, and anecdotal evidence of its value is already starting to come in. Other services in the pipeline include AIDS/HIV Question and Answer services and more about employment opportunities (Benjamin, 2006). E-Knowledge for Women in Southern Africa (EKOWISA) is a regional non-governmental 
organisation (NGO) based in Zimbabwe, which aims to generate, analyse, translate, repackage, and disseminate locally relevant information and knowledge for better livelihoods. By promoting the effective and efficient use of information communication technologies (ICTs), the organisation seeks to promote gender equality through knowledge creation, supporting women entrepreneurs, advocating for inclusive policy-making, and building ICT skills (E-knowledge For Women in Southern Africa 2008)

\section{Challenges of local content development in Africa}

There are several challenges for developing and managing local content especially with regard to IK. In Africa IK has suffered from lack of documentation, storage and retrieval using conventional information systems. Instead, it is stored in peoples' heads and hearts and is retrieved and communicated through non enduring means such as songs, dances, plays, drama, stories, and cultural rituals to mention a few. For decades, IK remained clouded and obscured by Westernschooled intellectuals, who often regarded such knowledge as backward and barbaric. Even today despite its wider use, there is limited awareness about the benefits of IK. The absence of laws to govern the practice and use of IK more than anything else explains how governments in Africa have contributed to the marginalisation of IK in favour of conventional knowledge.

UNESCO (2003) lists the following challenges associated with local content development and use: limited financial resources of developing countries for content production; inappropriate training opportunities for content creators; lack of access to advanced technology production units such as digital cameras, and digital studios; low motivation and commitment at the decision-making level to change the situation; and market forces, which do not encourage diversity. Other challenges include:

- Lack of local content across all media and information channels.

- Unequal content creation as most content comes from providers in the developed countries.

- Inadequate scope of content as many content reflects language, lifestyles and concerns that are different from those of end users.

- Inadequate intellectual property rights provisions arising from the fact that local content creators are not sufficiently recognised in IPR systems.

UNESCO (2006) states that the lack of local content is evident across all media and information channels. This is exemplified by the overwhelming presence of content on TV screens coming from content providers in the developed countries, reflecting language, values and lifestyles which are often vastly different from those of the community consuming the content. The agencies that push global or non-local content are more powerful and resourceful than those disseminating local content. ComDev (2008) observes that challenges associated with local content development are primarily associated with the sustainability and in particular include:

- Abrupt changes in external factors such as commodity prices, political transitions, or project characteristics which can result in substantial social and economic disruption.

- Dependence which can arise from failure to diversify the local and regional economy leading to solely relying on an individual company or sector.

- Disincentives especially when contractual local content targets become unsustainable if not flexible, carefully crafted, and regularly revisited.

- Cost escalation especially if there is overinvestment in local content thus draining company resources away from core business.

Africa is generally endowed with rich indigenous knowledge but the documentation of such knowledge to make it available in modern information systems for wider accessibility remains the greatest challenge. Besides, inadequate infrastructure including access to the Internet is the major problem affecting Africa's local content contribution especially, to the Web. Furthermore, the lack of cultural policies also mean that traditional ways of life, knowledge and know-how can disappear with the onslaught of foreign cultural models. This is exacerbated by weaknesses in content organisation, and absence of institutional framework for managing content.

The advent of globalisation driven by international politics, advancement in technology and the flexible mobility of human capital across borders, whilst providing opportunities for Africa, threatens the foundation of indigenous knowledge (Menchu 2007). This is partly because globalisation has led to deterioration of bio-cultural diversity through western-led bio-prospecting activities. The situation is exacerbated by the overbearing western media content, sophisticated technological capacity, aggressive multinational conglomerates, superior scientific innovation, and restrictive intellectual property regimes. Consequently, Africa's capacity to compete in the global knowledge age is in effect diminished.

Menchu (2007) acknowledges that though reliance on modern technologies has had improvements in communication and agriculture, social cohesion, knowledge and values, those they are intended to serve have been marginalised. 
Ballantyne (2002) observes that the powers that 'push' global or non-local content are often much stronger than those 'pushing' local content as reflected by over-reliance on foreign technical assistance, television programming, advertising, global brands, curricula and examinations, foreign languages in schools and universities.

Chivhanga (2000) points out that information gaps in developing countries especially, in Africa remain high despite the fact that local newspapers and books that provide information on various subjects have been with us for hundreds of years, while TV and radio have been instrumental in providing up-to-date information. Besides, most published materials used in Africa come from abroad in the form of key journals, textbooks, databases and variety of content in electronic media that are expensive to purchase. Ballantyne (2002) notes that though universities in Africa may generate large amounts of local content in terms of research and publications, research outcomes hardly find their way into international information systems. This, in part, is attributed to most of the content being offline. This is exacerbated by the fact that the average African university pays 50 times more for their bandwidth than their educational counterparts in the rest of the world (Fritz 2005 Citing Missen).

Woherem (1993) noted that the application of information and communication technology especially the computer has not be re-engineered for effective utilisation at grassroots level among communities that are not highly literate in Africa. Benjamin (1999) in the context of post-apartheid South Africa, has shown how community-based ICT projects have failed due to the use of non-participatory approaches during implementation. Agada (1999) bemoans that people in economically and socially marginalised communities have been found to spend an inordinate amount of time and energy seeking and managing information related to survival and security. Recent work in the area of digital government in the US revealed how the lack of appropriate access points amongst communities hinders the provision of social services by forcing individuals, often the poor, to travel long distances between offices (Bouguettaya et al. 200I). In Africa the situation is more dire because of lack of universal access to ICT facilities especially among rural people. A study carried out in rural Kenya by Prof Souter cited by Kenya Times (2005) on Economic Impact of Telecommunications on Rural Livelihoods and Poverty Reduction found that though the internet, is increasingly available through public service points in many rural areas, it is scarcely used. The findings also showed that although the internet is available in many local post offices and commercial outlets such as cyber cafes, fewer than $2 \%$ of the people interviewed think the internet is a very important tool for passing or receiving information.

Africa suffers from limited global Internet bandwidth. It is estimated that 98 percent of global internet bandwidth is connected to and from North America, a condition that forces countries in Africa to incur high costs (with payment in US or Canadian dollars), leading to cash flow in directions wholly counter to development (Gerhan and Mutula 2005). Fritz (2005) citing Missen, observes that Africa is a disconnected continent for many reasons. Telephone penetration is low sometimes as few as 20 phones per I,000 households. In addition, in many situations, the dial-in users share an Internet connection that is slower than their modem speed. Craig Barret chairman of Intel on a tour of Africa in 2007 commenting on poor state of the infrastructure noted ' we're just starting to see the internet take off, but the lack of broadband capability is a real retarding force on the internet in Africa' (Barret 2007). Besides, the media landscape is characterised by difficulties related to censorship, as well as to structural and legal obstacles in respect of the freedom of expression and development of a free press. The press in general lacks the independence to promote the right to print, publish and own press and media organs. Consequently, most people in Africa do not have access to information. Le Rouc (2003) notes that there is a fair amount of information on indigenous knowledge on the internet, but this knowledge is not readily accessible to all. In such circumstances, it is difficult for who have limited access to information to compete effectively in the global markets if they have, to decide which market in town they should take their crops based on competitive prices on offer. Without the capability to obtain this competitive information, businesses for example, become resources to be mined and eventually discarded, rather than being participants in the markets.

\section{Way forward}

The increasing momentum of developing and disseminating local content requires a systematic approach. The European Commission (European Commission, 2005) points out that digital content programmes are needed to ensure that content are more accessible, usable and exploitable in a multilingual environment. Such content programmes should also support preservation of digital collections in libraries, archives and museums so as to ensure availability of cultural, scholarly and scientific assets for future use.

ComDev (2008) proffers key steps for creating successful local content. These include:

- Encouraging a predictable regulatory and institutional environment that rewards investment in local content and enables multiplier and diversification impacts across the economy.

- Integrating local content into broader project and community development planning since local content is an important subset of broader community impact and development. This means that local content should not be implemented in 
isolation, but rather integrated into project planning and risk assessment as well as broader community development initiatives.

- Conducting a baseline needs and capabilities assessment with key stakeholders to understand community priorities, as well as existing skills.

- Establishing initial short and long term targets that are realistic. Besides, consideration should be given to partnerships with government or civil society to share accountability for meeting these targets and measuring success.

- Creating decision making processes and partnerships to maximise success. This is necessary to resolve conflicting priorities, address performance issues, and meet local community expectations.

- Monitoring and evaluating local content initiatives with stakeholder participation to enhance chances of success.

Besides, engaging stakeholders can improve data collection and help to communicate impact.

In addition to above recommendations, a broadcast policy and regulation. is important to facilitate scheduling of local content on radio and television stations. This is important given the frequent censorship of news that is common in some African countries. Moreover, the liberalisation of the media can allow a wider variety of content to be generated and disseminated. This can enrich media programming and also promote local production for the local media, along with foreign content. Governments can help in stimulating local content growth by providing tax breaks on production equipment and other materials and also encouraging co-production between foreigners and locals.

Local content is critical for Africa's full participation in the global knowledge society. To develop and nurture local content on the continent effectively requires multi-pronged approaches by African national governments with help from the international community. It is important for governments, industry, and researchers to work together to determine how best to utilise existing infrastructures (e.g. media, ISPs, cell phone providers, etc) with regard to documenting Africa's rich information and knowledge resources that are lying fallow. Information professionals on their part should take the lead in documentation and repackaging of information and knowledge and make it available as content in modern information systems, while the media could help to disseminate such content. The private sector should be encouraged and incentivised through social responsibility to fund community initiatives aimed at creating and documenting local content. The digitisation of documents, as well as creation of electronic databases that are of use to local communities should be encouraged. It is important to invest in training of information professionals and developing skills in Web design and digitisation of documents. It is also important to set up and maintain information gateways using software that address different languages, as well as strengthening copyright and intellectual property laws.

The success of different initiatives in enhancing content development and documentation would depend on the interventions that include promoting literacy; providing diversity of interfaces to document, store and access content; offering online education and support; promoting user centered methodology in building systems; providing high bandwidth for multimedia content; building institutional capacities to collect, organise, store and share information and knowledge; stimulating creation, processing, and dissemination of information to all people; provision of local content online; integrating ICT in the cultural milieu of the people (Woherem 1993); providing incentives to enhance content creation; and enabling access by the community to high bandwidth, efficient electricity grid, etc. Enhancing local content development involves putting in place effective 'push' mechanisms; increasing and improving the supply of content; focusing on the demand side so that local content is more highly valued; and improving the packaging of content so that the content is more attractive and accessible. Since it is not possible to have all the necessary capacities to create and disseminate content, partnerships are essential to overcome shortages in expertise (Ballantyne 2002).

\section{Conclusion}

Africa is no longer the information-poor continent that it used to be, but is well endowed with local content in the form of indigenous knowledge which if well harnessed and documented using modern ICT could transform the continent into a leading content provider among its counterparts in the world. What is needed is to intensify programmes for developing, managing and making content available through international modern information systems. In this way, Africa would effectively become an active participant in the knowledge age. The current international, regional, national and institutional efforts in local content development in Africa hold the key needed to transform it into a modern knowledge net exporter continent.

This paper has demonstrated that the term 'content' is mis-conceptualised and a new redefinition is proffered. The redefinition is aimed at making the cognate concept of 'local content' equally clearer. Efforts were also made to clarify the relationship between 'local content' and 'indigenous knowledge' that are often confusing. It was posited that contrary to widely held perceptions, Africa is making great strides with regard to local content development going by the several projects taking place on the continent. The paper discussed benefits and challenges associated with local content development. Finally, suggestions were made on how to successfully implement local content programmes.

SA Jnl Libs \& Info Sci 2008, 74(2) 


\section{References}

Africa Online Holdings Ltd. 2002. Africa Internet Status [Online] Available: http://www.africaonline.com/search/search.jsp?a=v\&Contentid=1952\&languageis=I [site accessed 4 February 2003].

Agada, J. 1999. Inner-city gate keepers: an exploratory survey of their information use environment. Journal of Information Science, 50 (I):74-85.

Aina, L.O and Mutula, S.M. 2005. Opportunities for electronic publishing in Africa. In: Thandike Mkandawire and Alois Mlambo (eds). African Scholarly Publishing. Oxford: INASP

Aznar, A. 2006. Africa animated!: initiative for African cartoons production [Online] available: http://portal.unesco.org/ci/en/

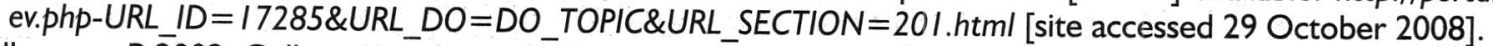

Ballantyne, P. 2002. Collecting and propagating local content development: synthesis and conclusions [Online] Available: http://portal.unesco.org/ci/en/files/5578//0342670280collecting_and_propagating_local_dev_Content.pdf/ collecting\%2Band\%2Bpropagating\%2Blocal\%2Bdev\%2BContent.pdf [site accessed 24 September 2007].

Benjamin, P. 2006. Open knowledge network, Africa programme [Online] Available: http://www.t4cd.org/Resources/ ICT_Resources/Projects/Pages/ICTProject_135.aspx [site accessed 29 October 2008].

Barret, C. 2007. Bridging Africa's digital divide. BBC News, I November 2007, I 1:47 GMT

Benjamin, P. 1999. Community development and democratization through information technology: building the new South Africa. In: Heeks (ed). Reinventing government in the information age: International practice in ICT-enabled public sector reform. London: Rutledge, 194-210.

Bouguettaya, A.; Ouzzani, M; Medjahead, B and Cameron, J. 200I. Helping citizens of Indiana: ontological approach to managing state and local government databases. IEEE Computer, February

Bourassa, R. 2003. Digital opportunities for Africa. Paper presented to the networking Africa's future conference. Pilanesburgh, South Africa, April 14-16, 2003.

Chikane, K. 2007. Welcome address EuroAfrica-ICT (START) FP7 awareness workshop October 8-9, 2007, Gaborone Botswana [Online] Available: http://euroafrica-ict.org/downloads/Awareness_Workshops/Botswana/K_Chikane.pdf (site accessed 19 October 2008).

Chivhanga, B.M. 2000. Internet use in Africa [Online] Available: http://www.egroups.com/group/africa_web_Content_owner [site accessed I2 April 2002]

Claiborne, S. 2005. What is content part I? [Online] Available: http://www.searchengineguide.com/scottie-claiborne/what-iscontent-part-i.php [site accessed 26 October 2008].

ComDev. 2008. Local content in supply chain [Online] Available: http://www.commdev.org/section/_commdev_practice/ local_content_in_supply_chain [site accessed 26 October 2008]

Crampton, M. 1998. NISC. Proceedings of the thirteenth standing conference of Eastern, Central and Southern African Librarians SCECSAL. 27-31 July 1998. Nairobi: BLA, 77-86

Department of Agriculture (South Africa). 2008. Agricultural intellectual property rights policy, draft 6. Pretoria: Department of Agriculture.

DOT Force. 200I. Digital opportunities for all: meeting the challenge [Online] Available: http://www.dotforce.org/reports/ DOT_Force_Report_V_5.0h.html [site accessed 22 April 2004].

Dusink, A.M. I99I. CTA's CD-ROM programme. Proceedings of the CDROM International Development. 16-18 December 1991. Washington DC: The World Bank.

E-knowledge For Women in Southern Africa. 2008. E-knowledge for women in Southern Africa (EKOWISA) [Online] Available: http://www.comminit.com/en/node/27/242 [site accessed 29 October 2008].

European Commission .2005. eContentplus programme [Online] Available: http://ec.europa.eu/information_society/activities/ eContentplus/index_en.htm [site accessed 25 April 2008].

Ford, H. 200I. African content in the multimedia age [Online] Available: http://www.eisa.org.za/category/technology/ Content I.htm [Site accessed 27October 2003].

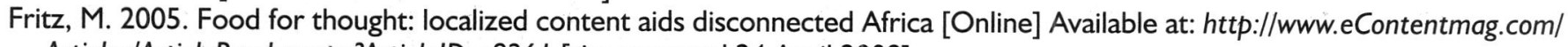
Articles/ArticleReader.aspx?ArticlelD=826I [site accessed 24 April 2008].

Graham, M. 1997. Use of information and communication technologies in IDRC projects: lessons learned, IDRC study/Acacia initiative [Online] Available: $h t t p: / / w w w . i d r c . c a / a c a c i a / o u t p u t s / o p-e v a l 3 . h t m$ [site accessed I3 November 2002].

Gerhan, D. and Mutula, S.M. 2005. Bandwidth bottlenecks at the University of Botswana: complications for library, campus, and national development. Library Hi Tech 23(I): 102-1 I7.

Harbi, M. 2003. New Partnership for Africa's Development (NEPAD): a bold initiative for Africa's revival [Online] Available: http://ww.itu.int/itunews/issue/2003/02/partnership.html [site accessed 26 October 2003].

International Institute of Communication and Development. 2002. IICD supported project: Open Knowledge Network (OKN). London: DFID.

International Federation of Library Associations. 2003. Libraries the information society in action [Online] Available: http:// www.ifla.org/III/wsis/Byrne-Plenary-Address.html [site accessed I4 February 2006].

International Record Management Trust. 2004. The e-records readiness tool. London: IRMT.

Jensen, M. 1999. Economic Commission for Africa-first meeting of the committee on development information (CODI) on the status of Africa information infrastructure. 28 July-2 August 1999. Addis Ababa: ECA

Kenya Times .2005. Economic impact of telecommunications on rural livelihoods and poverty reduction: A study of rural communities. Nairobi: Kenya Times.

Kirsop, B. 2002. The electronic publishing trust for development (EPT): putting developing country journals online. Santiago: Bioline Publications

Le Roux, C.J.B. 2003, Tapping indigenous knowledge on the world-wide web Indilinga African Journal of Indigenous Knowledge Systems, Vol 2, Issue I, 107-113 
The Linux Information Project. 2005. Content definition [Online] Available: $h t t p: / / w w w . b e l l e v u e l i n u x . o r g / c o n t e n t . h t m l$ [site accessed 26 October 2008].

Martindale, L. 2002. Cross digital language barriers: Translating software into local languages, INASP News Letter, No. 20 June, 7.

Menchu, R. (2007). Learning endogenous development: building on biocultural diversity. Bourton on Dunsmore, UK: Intermediate Technology Publications Ltd

Mikenga, S. 2005. Africa's first NEPAD e-school is launched in Uganda. Pretoria: Nepad e-Africa Commission.

Mutula, S.M. 2002. E-learning initiative at the University of Botswana: challenges and opportunities. Campus-Wide Information Systems, 19 (3):99-109

Mutula, S.M. 2006. E-governance and freedom of information in east and southern Africa: implications for development and human rights, Library Review 55(7):440-449.

Mutula, S.M.; Kalusopa, T; Moahi, K and Wamukoya, J. 2006. Design and implementation of an online information literacy module: experience of the department of library and information studies, University of Botswana, Online Information Review 30 (2): 168-187

National Forests Advisory Council. 200I. Changing the face of forestry in South Africa, The Star, November 27:19.

Naur, M. 200I, Indigenous knowledge and HIV/AIDS: Ghana and Zambia, IK Notes No. 30 March, pI -4

Office of Communications (Ofcom). 2006. Ofcom examines prospects for local digital content services [Online] Available: $h t t p: /$ /www.ofcom.org.uk/media/news/2006/01/nr_200601/9 [site accessed 25 September 2007].

Ojedokun, A.A. 2000. Prospects of digital libraries in Africa. African Journal of Library, Archives and Information Science, 10 (I): 1321.

Onyango, R. 1996. Indigenous technology capacity: can social intelligence help: a Kenyan case study. In: Blaise Cronin (ed). Information development and social intelligence. London: Taylor Graham Publishing, 164

Peters, D. and Pickover, M. 200I. Insights of an African model for digital library development. D-Lib Magazine, 7 (II) [Online] Available: $h t t$ ://www.dlib.org/dlib/november0I/peters/I Ipeters.html [site accessed 21 July 2005].

Pienaar, $\mathrm{H}$ and Deventer, M. 2007. Investigating the need for a virtual research environment (VRE) for malaria research in the South African context: a South African malaria initiative [Online] Available: http://www.acgt.co.za/sami/index.html [site accessed 9 May 2008].

Seepe, S. 200I. Indigenous knowledge systems, Mail \& Guardian, October 19: 22

Siemens, G. 2003. Content management: our organized future [Online] Available: http://www.elearnspace.org/Articles/Content management.htm. [site accessed 17 October 2006].

Souter, D. 2007. Whose summit? whose information society? civil society and WSIS. Paper presented at the Centre for the Study of Globalisation and Regionalisation $10^{\text {th }}$ Anniversary: A Workshop on Digital Divide: A Legal Postscript to the World Summit on Information Society. 17-19 September 2007. Warwick: University of Warwick.

Southwood, R. 2002. Mozambique grapples with how to make sense of Internet content, Balancing Act News Update 119.

Southwood, R. 2007. Kenya: country makes a technology leap with mobile TV. Balancing Act News, I November 2007, issue 16.

The Standard .2004. Enact policy to protect indigenous knowledge. Nairobi: The Standard Ltd.

Translate.org.za .2003. Open source software translation project [Online] Available $h t t p: / w w w . t r a n s l a t e . o r g . z a$ [site accessed 5 May 2003]

Ubogu, F. 2000. Spreading the ETD gospel: a Southern Africa perspective. Paper presented at the third international symposium on electronic theses and dissertations: applying new media to scholarship. 16-18 March 2000. St. Petersburg, Florida: University of South Florida

Ugwuanyi, E. 2003. FG loses N880b annually to capital flight in upstream activities, Vanguard, 8 October 2003 [Online] Available: $h$ ttp://fr.allafrica.com/stories/2003/008077l.html [site accessed 27 October 2003].

UNESCO .2003. Access to knowledge, open access, cultural and linguistic diversity, local. Paper presented At WSIS PrepCom II Multi-stakeholder Roundtable No. 2. [Online] Available: http://www.itu.int/wsis/docs/pc2/roundtables/rt2/khan.pdf [site accessed 26 October 2008].

UNESCO .2005. What is local content? [Online] Available: http://portal.unesco.org/ci/en/ev.php-

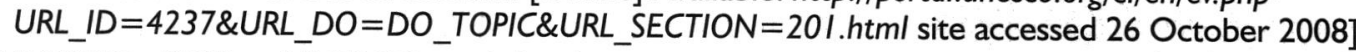

UNEŚCO .2005a. UNESCO and local content in the media [Online] Available: http://portal.unesco.org/ci/en/ev.php-

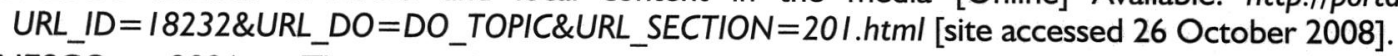

UNESCO .2006. The need for local content [Online] Available: http://portal.unesco.org/ci/en/ev.php-

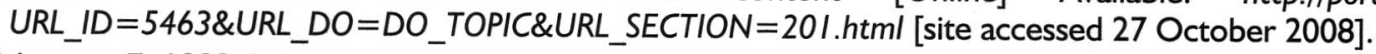

Woherem, E. 1993. Information technology in Africa: challenges and opportunities. Nairobi: ACTS.

WordReference .2008. Content [Online] Available: http://www.wordreference.com/definition/content [site accessed 26 October 2008]

The World Bank Group 2008. Integrating IK in bank-supported projects [Online] Available: http://web.worldbank.org/WBSITE/EXTERNAL/COUNTRIES/AFRICAEXT/EXTINDKNOWLEDGE/

0, contentMDK:20663846 menuPK: I I 4492 pagePK:64 I 68445 piPK:64 I 68309 theSitePK:825547,00.html [site accessed 12 May 2008].

World Summit on the Information Society. 2003. Declaration of principles and plan of action [Online] Available: http://www.itu.int/wsis/documents/doc_multi. asp? lang=en\&id= I I61 | I I 60 [site accessed 26 September 2007].

World Summit on the Information Society. 2005. Tunis commitment and Tunis agenda for the information society [Online] Available: http://www.itu.int/wsis/ocuments/doc_multi.asp? lang=en\&id=2266|2267 [site accessed I4 February 2006].

SA Jnl Libs \& Info Sci 2008, 74(2) 